\title{
Plasma amyloid $\beta$ levels in Alzheimer's disease and cognitively normal controls in Syrian population
}

\author{
Rafah Manafikhi*1 $\mathbb{1}$, M. Bassam Haik², Raghda Lahdo³ Faizeh AlQuobaili $^{1}$ \\ Received: 8 Jun 2020 \\ Published: 8 Feb 2021
}

\begin{abstract}
Background: The pathogenesis of Alzheimer's disease (AD) is believed to be occurred by the production of neurotic plaques of the beta-amyloid peptide $(A \beta)$ and deposition of them. Therefore, biomarkers of abnormal $A \beta$ processing may represent before the AD clinical biomarkers, which could be benefit for a successful disease management that may prevent the AD development. The aim of this study is to investigate of plasma $A \beta 40,42$ levels in Alzheimer's patients in Syria and thus determine whether they may have a potential role as biomarker for identifying and predicting AD.

Methods: In this cross-sectional study, the plasma levels of $A \beta 1-40$ and $A \beta 1-42$ were investigated in two groups represent Syrian population, $\mathrm{AD}$ group; clinically diagnosed $\mathrm{AD}$ patients $(\mathrm{n}=50)$ and $\mathrm{CN}$ group; cognitively normal participants $(\mathrm{n}=33)$. This study first determined the reference interval of plasma $A \beta 1-40$ and A $\beta 1-42$ for cognitively normal Syrian. Results were analyzed using SPSS, 24, depending on independent-samples $t$ test, considering that the value of $p<0.05$ is statistically significant.

Results: The results showed that the plasma levels of A $\beta 1-40(p<0.001$, OR=1.031, 95\%CI: 1.012-1.051) and A $\beta 1-42(p<0.001$, $\mathrm{OR}=1.306,95 \% \mathrm{CI}: 1.145-1.490$ ) were significantly higher in $\mathrm{AD}$ patients than in cognitively normal participants, and no significant association was shown between both of education and sex with plasma $\mathrm{A} \beta$ levels.
\end{abstract}

Conclusion: The plasma levels of A $\beta 1-40$ and $A \beta 1-42$ could be potential biomarkers for identifying and predicting AD.

Keywords: Alzheimer disease, A $\beta 40,42$, Biomarkers, Syria

Conflicts of Interest: There is no conflict of interest

Funding: Aleppo University

*This work has been published under CC BY-NC-SA 1.0 license.

Copyright $\odot$ Iran University of Medical Sciences

Cite this article as: Manafikhi R, Haik MB, Lahdo R, AlQuobaili F. Plasma amyloid $\beta$ levels in Alzheimer's disease and cognitively normal controls in Syrian population. Med J Islam Repub Iran. 2021 (8 Feb);35:19. https://doi.org/10.47176/mjiri.35.19

\section{Introduction}

According to the World Health Organization (WHO), worldwide, around 50 million people have dementia, and there are nearly 10 million new cases every year. The total number of people with dementia is expected to reach 82 million in 2030 and 152 million in 2050. Alzheimer's disease (AD) is the most common form of dementia and could contribute to 60-70 percent of cases. World Health Organization reveals that abou $\mathrm{t} 60 \%$ of all people living with dementia worldwide are from a low to middle in-

Corresponding author: Rafah Manafikhi, rafahmanafikhi@gmail.com

1. Department of Biochemistry and Microbiology, Faculty of Pharmacy, University of Damascus, Syria

2. General Manager of the General Committee of Ibn Khaldun Hospital, Aleppo, Syria

3. Department of Biochemistry and Microbiology, Faculty of Pharmacy, University of Aleppo, Syria come countries (1).

$\mathrm{AD}$ is characterized by a gradual and progressive decline in cognitive functions and the presence of specific neuron and synapse loss in addition to the senile plaques and neurofibrillary tangles. For diagnosis of $\mathrm{AD}$, the presence of neurotic plaques (composed of highly insoluble amyloid- $\beta(\mathrm{A} \beta)$ peptide in large part) in the brain parenchyma is needed. This concept suggests that a plaque deposition occurs as a result of chronic imbalance between

\section{$\uparrow$ What is "already known" in this topic:}

$\mathrm{A} \beta$ is a biomarker that plays an important role in $\mathrm{AD}$ diagnosis, where it accumulates in the brain and forms plaques that lead to neurons damage. There are many studies, in several countries, that investigate $\mathrm{A} \beta$ plasma levels in $\mathrm{AD}$ patients and there is a contradiction in their results.

$\rightarrow$ What this article adds:

In Syria, there are no studies on the normal and pathological plasma values of $A \beta$. It is the first study on plasma levels of $A \beta$ in $\mathrm{AD}$ patients in Syrian population. 
production the amyloid-beta peptide and clearance of it (2).

The beneficial roles of amyloid- $\beta$ involve repairing leaks in the blood-brain barrier (BBB), contributing in healing the injury, protecting the body from infections and controlling synaptic perform. Evidence for these putative roles comes from in vivo and in vitro studies, which showed that amyloid- $\beta$ generation increases rapidly in a physiological challenge response and usually reduces once healing (3).

A biomarker or biological marker, assesses as an index of normal biological functions, pathogenic conditions or responses to a therapeutic procedures. A biological marker can evaluate as an indicator of healthiness and illness (4).

Amyloid precursor protein (APP) gene is expressed in the brain and other parts of the body tissues. The molecular mechanism implicated in APP breakage down and amyloid- $\beta$ synthesis has yet to be determined precisely (5).

Amyloid- $\beta$ peptide is produced by a number of actions of alpha $(\alpha)$, beta $(\beta)$ and gamma $(\gamma)$ secretases on APP. Amyloid- $\beta$ is generated in the endoplasmic reticulum (ER), Golgi apparatus and endosomal compartment by the action of $\beta$-secretase and $\gamma$-secretase (6). Therefore, several amyloid- $\beta$ pieces have been produced, but those ending at location $40(\mathrm{~A} \beta 1-40)$ are the mos plentiful (approximately 80-90 percent), then those ending at location 42 (A $\beta 1-42$, approximately 5-10 percent). The somewhat longer species of amyloid- $\beta$, mainly $A \beta 1-42$, have more hydrophobicity and fibrillogenesis properties, and they are the mainly pieces positioned into the brain (7).

Taking cerebrospinal fluid (CSF) samples is an annoying procedure with probable side effects, with the difficulties in screening of patients and making follow-up studies of the same patient for many years. So, there is an urgent need to do researches for determining biomarkers in other body fluids such as blood to make an accurate diagnosis of Alzheimer's disease (8).

It is not comprehended yet how the blood molecule level associates with pathological alterations in the brain, particularly in Alzheimer's disease. Therefore, identifying biomarkers in the blood that associate with Alzheimer's disease must initiates with established biomarkers in CSF, such as biomarkers linked to amyloid- $\beta$ and tau protein (4). Furthermore, there is no accepted reference values for amyloid- $\beta$ in the plasma. A study of the reference values of $A \beta$ in the plasma for cognitively normal Korean adults revealed that the 95 th percentile reference values for $A \beta 1$ 40 were $127-331 \mathrm{pg} / \mathrm{mL}$ and for $\mathrm{A} \beta 1-42$ were $2.31-19.84$ $\mathrm{pg} / \mathrm{mL}(9)$. Another study in Poland showed that the plasma levels of $A \beta 1-40$ and $A \beta 1-42$ in control group were $160.1 \pm 15.2 \mathrm{pg} / \mathrm{mL}$ and $36.3 \pm 6.3 \mathrm{pg} / \mathrm{mL}$, respectively (10). A study in USA found that the $A \beta 40$ and $A \beta 42$ plasma levels in control were $211.4 \pm 74.4,31.6 \pm 14.0 \mathrm{pg} / \mathrm{mL}$ respectively (11). Further researches are needed to identify clear reference interval in other countries.

In Syria, there are no studies on the normal and pathological plasma values of $A \beta$. So that, there is an urgent need to more studies related to this field. The fact that the pathophysiological alterations associated with Alzheimer's disease begin several years before the appearance of clini- cal cognitive complaints (12). Thus, it's necessary to determine biomarkers that help in early AD diagnosis.

\section{Methods}

\section{Study Subjects}

This was cross-sectional study in Syria, it was conducted over a period of two months. Samples were collected from Ibn Khaldoun Psychosocial Support Committee, nursing homes and private clinics in Aleppo city. Patients with diagnosed Alzheimer's disease (AD) $(n=50)$ and cognitively normal subjects $(\mathrm{CN})(\mathrm{n}=33)$ aged above 60 years (60-100 years for $\mathrm{AD}, 60-89$ years for $\mathrm{CN}$ ) are involved in this study.

Exclusion criteria of participants: A history of cardiovascular diseases.

Alzheimers' subjects were included in our study if their disease was diagnosed by neurologists after they received a detailed clinical history, neurological examination in addition to assessment of activities of daily living and the Mini-Mental State Examination (MMSE) criteria (should be below 24 points), and this is the protocol used and approved for diagnosis by neurologists in Syria. Healthy controls were included in our study if no familial or personal cognitive impairment or psychiatric history were reported, neurological examination by neurologists was normal and the MMSE (Arabic version) score was above 26 points (bearing in mind that in the Spanish population, the MMSE cut off value has been illustrated to be <25) (13).

This study was approved by the Ethical Committee, Faculty of Pharmacy, Damascus University. All participants volunteers (or their guardians) were informed by the aim of the study and a permit was obtained from each subject (or his/her guardian) to participate in this study.

\section{Plasma AB quantification}

Venous blood samples $(5 \mathrm{~mL})$ were collected into tubes containing EDTA as anticoagulant. Plasma samples were aliquoted into polypropylene tubes (two tubes, $250 \mu \mathrm{L}$ in each one) after centrifugation, and stored at $-20{ }^{\circ} \mathrm{C}$.

Plasma was used to quantify amyloid- $\beta 1-40$ and amyloid- $\beta 1-42$ by using Sandwich ELISA method (EUROIMMUN Medizinische Labordiagnostika AG. Lubeck, Germany) depending on monoclonal anti-beta-amyloid antibodies.

\section{Statistical analysis}

Results are expressed as mean \pm SD. Results were analyzed using SPSS 24 statistical program, depending on Independent-samples $\mathrm{T}$ Test and chi-square $(\chi 2)$ test considering that the value of $\mathrm{p}<0.05$ is statistically significant. Normal distribution was checked using a ShapiroWilk test. Odds ratio (OR) was calculated to evaluate the association with $\mathrm{AD}$, the association is considered when $\mathrm{OR} \neq 1$. The corresponding $95 \%$ confidence intervals (CIs) were also calculated. 


\section{Results}

A61-40 and A61-42 levels in AD group and CN group

Plasma $A \beta$ levels were investigated in 83 subjects; AD group (clinically diagnosed $\mathrm{AD}$ patients, $\mathrm{n}=50 ; 19$ men and 31 women, 41 workers and 9 employees) and $\mathrm{CN}$ group (control group of cognitively normal subjects, $\mathrm{n}=33 ; 15$ men and 18 women, 24 workers and 9 employees) (Table 1).

The comparison between both groups showed that the plasma levels of both $A \beta 1-40$ and $A \beta 1-42$ were higher in AD patients (AD group) than in cognitively normal participants (CN group) and this augmentation of $A \beta$ was significant for both $A \beta 1-40(p<0.001, O R=1.031,95 \% C I$ : $1.012-1.051)$ and $\mathrm{A} \beta 1-42(\mathrm{p}<0.001, \mathrm{OR}=1.306,95 \% \mathrm{CI}$ : 1.145-1.490), taking into account that individuals in both groups are of the same age group and that they are matched in gender and the number of the educated and uneducated, and no significant difference was shown between both groups ( $\mathrm{AD}$ and $\mathrm{CN}$ ) with regard to age, education and sex $(\mathrm{p}>0.05)$ (Table 1$)$.

Figure 1 shows the results of $A \beta 1-40$ levels in $A D$ group and $\mathrm{CN}$ group; $155.95 \pm 39.08 \mathrm{pg} / \mathrm{mL}$ and $118.96 \pm 34.94 \mathrm{pg} / \mathrm{mL}$, respectively. Also this figure shows the mean values of $\mathrm{A} \beta 1-42$ levels in $\mathrm{AD}$ group and $\mathrm{CN}$ group; $25.25 \pm 22.16 \mathrm{pg} / \mathrm{mL}$ and $8.39 \pm 6.59 \mathrm{pg} / \mathrm{mL}$ respectively.

Levels of A61-40, AB1-42 according to gender and Job

Table 2 shows that there is no significant difference in $\mathrm{A} \beta$ levels between the educated (employees) and the uneducated (workers) subjects in $\mathrm{AD}$ group. Our results show that there is also insignificant difference between $A \beta$

Table 1. Characteristics of Subjects involved in the study and levels of A $\beta 1-40, A \beta 1-42$

\begin{tabular}{|c|c|c|c|c|c|}
\hline \multirow[t]{2}{*}{ Variable } & & \multirow[t]{2}{*}{ Total } & \multicolumn{2}{|c|}{ Groups } & \multirow[t]{2}{*}{$\mathrm{p}$} \\
\hline & & & $\mathrm{AD}$ & $\mathrm{CN}$ & \\
\hline $\bar{N}$ & & 83 & 50 & 33 & \\
\hline Age & & $\begin{array}{c}>60 \\
(60-100)\end{array}$ & $\begin{array}{c}>60 \\
(60-100)\end{array}$ & $\begin{array}{c}>60 \\
(60-89)\end{array}$ & 0.568 \\
\hline Gender & $\begin{array}{c}\text { Female n }(\%) \\
\text { Male n }(\%)\end{array}$ & $\begin{array}{l}49(59.04 \%) \\
34(40.96 \%)\end{array}$ & $\begin{array}{l}31(62 \%) \\
19(38 \%)\end{array}$ & $\begin{array}{l}18(54.55 \%) \\
15(45.45 \%)\end{array}$ & 0.499 \\
\hline Job & $\begin{array}{l}\text { Workers n }(\%) \\
\text { (uneducated) }\end{array}$ & $18(21.69 \%)$ & $9(18 \%)$ & $9(27 \%)$ & 0.502 \\
\hline & $\begin{array}{l}\text { Employees n (\%) } \\
\quad \text { (educated) }\end{array}$ & $65(78.31 \%)$ & $41(82 \%)$ & $24(72.73 \%)$ & \\
\hline $\begin{array}{l}\mathrm{A} \beta 1-40 \\
\mathrm{pg} / \mathrm{mL}\end{array}$ & mean $\pm \mathrm{SD}$ & _ & $155.95 \pm 39.08$ & $118.96 \pm 34.94$ & $<0.001$ \\
\hline $\begin{array}{l}\mathrm{A} \beta 1-42 \\
\mathrm{pg} / \mathrm{mL}\end{array}$ & mean $\pm \mathrm{SD}$ & - & $25.25 \pm 22.16$ & $8.39 \pm 6.59$ & $<0.001$ \\
\hline
\end{tabular}

AD: Alzheimer Disease, CN: Cognetively Normal, A $\beta$ : Amyloid- $\beta$, SD: Std. Deviation

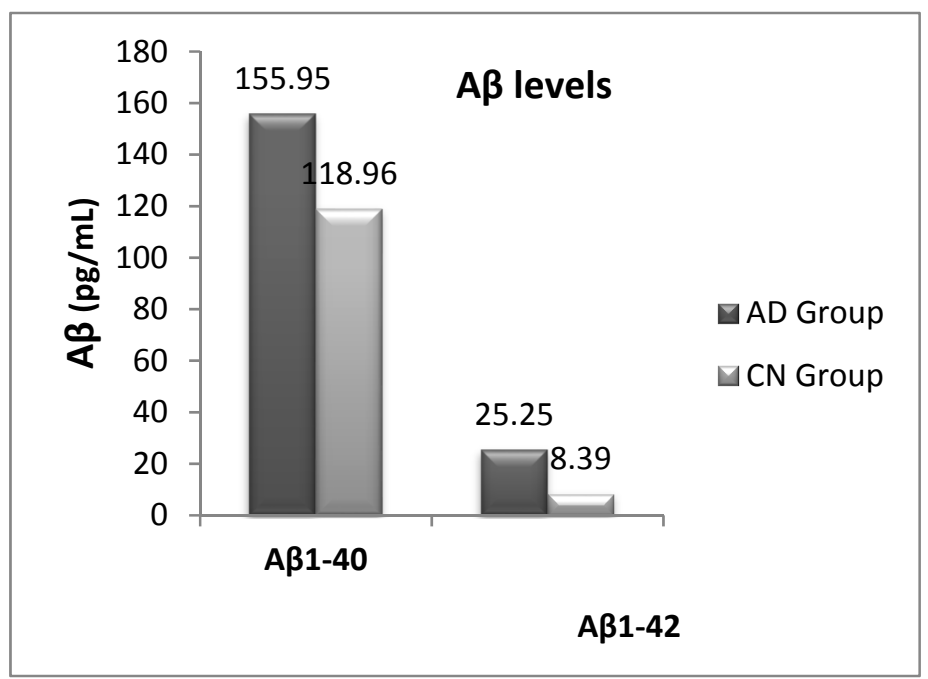

AD: Alzheimer Disease, CN: Cognetively Normal, A $\beta$ : Amyloid- $\beta$

Fig. 1. Mean values of $\mathrm{A} \beta 1-40$ and $\mathrm{A} \beta 1-42$ levels in $\mathrm{AD}$ group and $\mathrm{CN}$ group

Table 2. Levels of A $\beta 1-40, \mathrm{~A} \beta 1-42$ according to gender and Job

\begin{tabular}{|c|c|c|c|c|c|c|}
\hline & \multicolumn{3}{|c|}{ Sex } & \multicolumn{3}{|c|}{ Job } \\
\hline & Female & Male & $\mathrm{p}$ & $\begin{array}{c}\text { Workers } \\
\text { (uneducated) }\end{array}$ & $\begin{array}{l}\text { Employees } \\
\text { (educated) }\end{array}$ & $\mathrm{p}$ \\
\hline $\mathrm{AD}(\mathrm{n})$ & 31 & 19 & & 41 & 9 & \\
\hline $\mathrm{A} \beta(1-42) \mathrm{pg} / \mathrm{mL}$ mean $\pm \mathrm{SD}$ & $23.16 \pm 14.81$ & $20.43 \pm 9.70$ & 0.518 & $15.48 \pm 4.10$ & $16.00 \pm 0.40$ & 0.835 \\
\hline
\end{tabular}


levels in males and females in AD group.

\section{Discussion}

\section{$A B 1-40$ and $A B 1-42$ levels in $A D$ group and $C N$ group}

The plasma levels of both $A \beta 1-40$ and $A \beta 1-42$ in our study are close to other studies $(10,14)$. Our results are in accordance with a study in Taiwanese cohorts that revealed a significant increase in the plasma levels of A $\beta 1-42$ in mild cognitive impairment (MCIs) individuals, and in early stages of Alzheimer's disease (15). The $\mathrm{A} \beta 1-42$ is less recurrent than $A \beta 1-40$. However, it deposits much earlier and accumulates more quickly in comparison with $\mathrm{A} \beta 1-40$ (16).

Our results were consistent with the results of previous clinical studies $(10,14,17)$ which had found also that the plasma levels of both $A \beta 1-40$ and $A \beta 1-42$ were higher in AD patients than in cognitively normal people. These results may be explained depending on the assumption of other studies which suggested that the circulating amyloid- $\beta$ may inflow via $\mathrm{BBB}$ and promote the accumulation of amyloid- $\beta$ in the brain. Since the expression of APP occurs in several tissues in addition to the brain. Therefore, the levels of amyloid- $\beta$ can be detected in the blood (18). Normally, liver and kidneys facilitate the circulating amyloid- $\beta$ systematic clearance through identified transporter. Thus, the circulating amyloid- $\beta$ level increases when the systematic clearance is defective as in Alzheimer's disease patients, in addition to that the free circulating amyloid- $\beta$ would be augmented by the increasing of oxidative damage which happens in Alzheimer's disease damage (18).

A study on rodents showed that the circulating amyloid- $\beta$ may flow through the BBB (19), by identified receptor of advanced glycation end products (RAGE), and a RAGE up-regulation was noticed in Alzheimer's disease human patients.

On the other hand, other studies $(20,21)$ found that the levels of plasma amyloid- $\beta$ were lower in AD patient than in cognitively normal people. This may be due to the assumption of that the BBB won't clear the amyloid- $\beta$ from CSF into the blood through specific lipoprotein receptor related protein 1 (LRP-1) due to its dysfunction which could happen in Alzheimer's disease, and thus contribute to aggregation of amyloid- $\beta$ in the brain (22).

These conflicting results could be as a result of several factors that can affect the plasma amyloid- $\beta$ peptide level as it has been suggested in some studies $(23,24)$, for instance, sex, age, levels of plasma proteins, function of kidney, race and stage of disease. Amyloid- $\beta$ peptides in plasma are bound to other plasma proteins easily and broken down in the blood (25). So, the results of plasma amyloid- $\beta$ could be affected by the levels of total protein.

Variances in studies cohort, such as cognitive decline stage, cognitive function estimation (by various examinations), treatment and other illnesses, all of these issues can affect the results of different studies (26). Plasma amyloid- $\beta$ may be increased by alterations in renal function, since plasma amyloid- $\beta$ is normally excreted via the kidneys (27). The traditional technique of quantifying the plasma amyloid- $\beta$ is sandwich ELISA, but the plasma proteins and lipoproteins could affect immunological detection (28). In addition to that, soluble amyloid- $\beta$ pieces bind to numerous proteins, for instance, albumin as well as other proteins. These complexes could affect ELISA immunoreactions and also influence the results (29).

\section{Levels of A61-40, AB1-42 according to gender and Job}

Our results are consistent with those of some studies that have not found a significant correlation between amyloid- $\beta$ levels and education (30). But it contrasts with other studies that have shown a statistical association with education (31). Our results show that there is also insignificant difference between $A \beta$ levels in males and females in $\mathrm{AD}$ group, and this is consistent with the result of other study on African American that did not find a significant difference between men and women in terms of levels of amyloid beta (32), but it contradicted on the other hand with other clinical studies that showed a significant correlation between sex and levels of amyloid beta (31).

The limitations of this study are the relatively small sample size in addition to that the patients are not classified according to the stages of the disease. So, further researches and studies are recommended with considering the stages of disease, increasing size of sample, and adjusting the study conditions.

\section{Conclusion}

In conclusion, plasma beta-amyloid 40 and 42 may be important biomarkers and could help in Alzheimer's disease diagnosis.

\section{Acknowledgement}

Authors are thankful the Center of Ibn Khaldoun Psychosocial Support Committee, Department of Laboratory Medicine, Aleppo University Hospital and Laboratories of the Faculty of Science, Aleppo University for their help in this study.

\section{Conflict of Interests}

The authors declare that they have no competing interests.

\section{References}

1. World Health Organization. Dementia. 19 September 2019. Available from: https://www.who.int/news-room/fact-sheets/detail/dementia.

2. Hardy J, Selkoe DJ. The amyloid hypothesis of Alzheimer's disease: progress and problems on the road to therapeutics. Science. 2002;297:353-356.

3. Holly B, Maya G, Stephen R. The Physiological Roles of Amyloid- $\beta$ Peptide Hint at New Ways to Treat Alzheimer's Disease. Front Aging Neurosci. 2018;10:118.

4. Christian H. Identifying and validating biomarkers for Alzheimer's disease. Trends Biotechnol. 2011;29(1):26-32.

5. Raghda L, Stéphane C.M, Jean P.C, Laurence F.B. The amyloid precursor protein interacts with neutral lipids Liposomes and monolayer studies. Eur J Biochem. 2002;269(8): 2238-2246.

6. Esler WP, Kimberly WT, Ostaszewski BL, Diehl TS, Moore CL, Tsai JY, et al. Transition-state analogue inhibitors of c-secretase bind directly to presenilin-1. Nature Cell Biol. 2000;2:428-434.

7. Selkoe DJ. Alzheimer's disease: genes, proteins, and therapy. Physiol Rev. 2001;81:741-766.

8. Blennow K. Cerebrospinal fluid and plasma biomarkers in Alzheimer disease. Nat Rev Neurol. 2010;6:131-144. 
9. Min K, Kyu K, Hye Ch, Duck L, Doo Ch. Reference Intervals for Plasma Amyloid $\beta$ in Korean Adults Without Cognitive Impairment. Ann Lab Med. 2016;36(6):595-598.

10. Sobow T, Flirski M, Kloszewska I, Liberski PP. Plasma levels of alpha beta peptides are altered in amnestic mild cognitive impairment but not in sporadic Alzheimer's disease. Acta Neurobiol Exp (Wars) 2005;65:117-124.

11. Fukumoto H, Tennis M, Locascio JJ, Hyman BT, Growdon JH, Irizarry MC. Age but not diagnosis is the main predictor of plasma amyloid beta-protein levels. Arch Neurol. 2003;60:958-964.

12. Blennow K, de Leon MJ, Zetterberg H. Alzheimer's disease. Lancet. 2006;368:387-403.

13. Blesa R, Pujol M, Aguilar M, Santacruz P, Bertran-Serra I, Hernández $\mathrm{G}$, et al. Clinical validity of the 'mini-mental state' for Spanish speaking communities. Neuropsychologia. 2001;39:11501157.

14. Fagan AM, Roe CM, Xiong C, Mintun MA, Morris JC, Holtz-man DM. Cerebrospinal fluid tau/beta-amyloid(42) ratio as a prediction of cognitive decline in nondemented older adults. Arch Neurol. 2007;64:343-349.

15. Chiu MJ, Yang SY, Chen TF, Chieh JJ, Huang TZ, Yip PK, et al. New assay for old markers-plasma beta amyloid of mild cognitive impairment and Alzheimer's disease. Curr Alzheimer Res. 2012;9:1142-1148.

16. Takeshi I, Asano O, Nobuhiro S, Hidehiro M, Nobuyuki N, Yasuo I. Visualization of Ab42(43) and Ab40 in senile plaques with specific ab monoclonals: evidence that the initially deposited species is Ab42(43). Neuron. 1993;13:45-53.

17. Roher AE, Esh CL, Kokjohn TA, Castano EM, Van Vickle GD, Kalback WM, et al. Amyloid beta peptides in human plasma and tissues and their significance for Alzheimer's disease. Alzheimers Dement. 2009;5:18-29.

18. Michelle AE, William AB. Blood-brain barrier dysfunction as a cause and consequence of Alzheimer's disease. J Cereb Blood Flow Metab. 2013;33, 1500-1513.

19. Zlokovic BV, Ghiso J, Mackic JB, McComb JG, Weiss MH, Frangione B. Blood-brain barrier transport of circulating Alzheimer's amyloid beta. Biochem Biophys Res Commun. 1993;197:1034-1040.

20. Buerger K, Frisoni G, Uspenskaya O, Ewers M, Zetterberg H, Geroldi C, et al. Validation of Alzheimer's disease CSF and plasma biological markers: the multicentre reliability study of the pilot European Alzheimer's Disease Neuroimaging Initiative (E-ADNI) Exp Gerontol. 2009;44:579-585.

21. Giedraitis V, Sundelof J, Irizarry MC, Garevik N, Hyman BT, Wahlund LO, et al. The normal equilibrium between CSF and plasma amyloid beta levels is disrupted in Alzheimer's disease. Neurosci Lett. 2007;427:127-131.

22. Zlokovic BV. Neurovascular mechanisms of Alzheimer's neurodegeneration. Trends Neurosci. 2005;28:202-208.

23. Toledo JB, Shaw LM, Trojanowski JQ. Plasma amyloid beta measurements-a desired but elusive Alzheimer's disease biomarker. Alzheimers Res Ther. 2013;5:8.

24. Rembach A, Watt AD, Wilson WJ, Villemagne VL, Burnham SC, Ellis KA, et al. Plasma amyloid- $\beta$ levels are significantly associated with a transition toward Alzheimer's disease as measured by cognitive decline and change in neocortical amyloid burden. J Alzheimers Dis. 2014;40:95-104.

25. Wilson MR, Yerbury JJ, Poon S. Potential roles of abundant extracellular chaperones in the control of amyloid formation and toxicity. Mol Biosyst. 2008;4:42-52.

26. Seppala TT, Herukka SK, Hanninen T, Tervo S, Hallikainen M, Soininen H, et al. Plasma A $\beta 42$ and A $\beta 40$ as markers of cognitive change in follow-up: A prospective, longitudinal, population-based cohort study. J Neurol Neurosurg Psychiatry. 2010;81(10):1123-7.

27. Arvanitakis Z, Lucas JA, Younkin LH, Younkin SG, Graff-Radford NR. Serum creatinine levels correlate with plasma amyloid Beta protein. Alzheimer Dis Assoc Disord. 2002;16:187-90.

28. Kawarabayashi T, Shoji M. Plasma biomarkers of Alzheimer's disease. Curr Opin Psychiatry. 2008;21:260-267.

29. Takeda S, Sato N, Rakugi H, Morishita R. Plasma beta-amyloid as potential biomarker of Alzheimer disease: possibility of diagnostic tool for Alzheimer disease. Mol Biosyst. 2010;6:1760-1766.

30. Toledo JB, Vanderstichele H, Figurski M, Aisen PS, Petersen RC, Weiner MW, et al. Factors affecting $A \beta$ plasma levels and their utility as biomarkers in ADNI. Acta Neuropathol. 2011;122:401-413.
31. Metti AL, Cauley JA, Ayonayon HN, Harris TB, Rosano C, Williamson JD, et al. The Demographic and Medical Correlates of Plasma Abeta40 and Abeta42. Alzheimer Dis Assoc Disord. 2013 JulSep; 27(3): 244-249.

32. Green RC, Cupples LA, Go R, Edeki T, Griffith PA, Williams M, et al. Risk of dementia among white and African American relatives of patients with Alzheimer disease. JAMA. 2002;287(3):329-36. 